\title{
Vaccination of harbour seals (Phoca vitulina) against phocid distemper with two different inactivated canine distemper virus (CDV) vaccines
}

\author{
I.K.G. Visser*, M.W.G. v.d. Bildt*, H.N. Brugge ${ }^{\S}$, P.J.H. Reijnders ${ }^{\ddagger}$, E.J. Vedder*, \\ J. Kuiper ${ }^{\S}$, P. de Vries ${ }^{\dagger}$, J. Groen ${ }^{\dagger}$, H.C. Walvoort ${ }^{\dagger}$, F.G.C.M. UytdeHaag ${ }^{\dagger}$ \\ and A.D.M.E. Osterhaus ${ }^{\dagger}$
}

Two inactivated canine distemper virus (CDV) vaccines-an adjuvanted whole inactivated virus and a subunit ISCOM preparation-were tested for their ability to induce protective immunity in harbour seals (Phoca vitulina) against phocid distemper, a disease that recently killed $>17000$ harbour seals in the North and Baltic seas, and was shown to be caused by infection with a newly discovered morbillivirus, which is antigenically closely related to $C D V$. Four $C D V$ seronegative harbour seals were vaccinated three times with the whole-virus vaccine, two with the ISCOM subunit vaccine and two were sham-vaccinated with an antigen-free preparation. Ten days after the last vaccination, when all six vaccinated animals had developed $C D V$ neutralizing antibody titres ranging from 300 to 3000 , all eight animals were challenged by the oculonasal and the peritoneal routes, with an organ suspension from dead seals. None of the six vaccinated animals developed clinical signs. The two sham-vaccinated seals died on days 14 and 18 , respectively, after having shown a body temperature rise, respiratory symptoms and weight loss. In organs from both dead animals morbillivirus antigen was demonstrated with an enzyme-linked immunosorbent assay and an immunofluorescence assay. One of these two animals had developed a low titre of $C D V$-specific antibodies just before death. These data clearly indicate that seals can be protected from fatal challenge with the phocid distemper virus $(P D V)$, by vaccination with certain inactivated $C D V$ vaccines. They also reconfirm that infection with $P D V$ should be considered the primary cause of the recent epizootic in seals.

Keywords: Inactivated CDV vaccine; ISCOM; phocid distemper; harbour seals; protection

\section{Introduction}

Since April $1988>17000$ harbour seals have died in the North and Baltic seas, during an outbreak of an acute infectious disease $\mathrm{e}^{1-3}$. The primary cause of the disease proved to be infection with a newly discovered morbillivirus, phocid distemper virus (PDV), which was antigenically closely related to canine distemper virus $(\mathrm{CDV})^{4-9}$. Apart from abortion, which was mainly observed at the beginning of the outbreak when most pups of that season were still to be born, the clinical signs were fairly similar to those observed in canine distemper ${ }^{4,5,9,10}$ : they included respiratory and gastrointestinal symptoms, neurological signs, cutaneous lesions, general depression and also a variety of secondary viral, bacterial and parasitic infections ${ }^{2,4,9,11}$. Experimental infection of specified pathogen-free (SPF) dogs resulted in a mild form of clinical distemper, as also proved to

* Seal Rehabilitation and Research Centre, Pieterburen, The Netherlands. ${ }^{\dagger}$ National Institute of Public Health and Environmental Protection, Bilthoven, The Netherlands. ${ }^{\ddagger}$ Research Institute for Nature Management, Texel, The Netherlands. ¿EcoMare, Wadden and North Sea Centre, Texel, The Netherlands. (Received 22 May 1989; revised 27 July 1989; accepted 3 August 1989) be the case when SPF dogs were infected with a fully virulent strain of $\mathrm{CDV}^{12}$.

Although preventive vaccination in wild animal species should generally not be recommended, there proved to be an urgent need for a vaccine during the outbreak in sanctuaries, aquaria and for certain isolated groups of seals of particular value ${ }^{13}$. In the absence of a suitable large-scale production system for PDV and in the light of the close antigenic relationship with CDV, the use of CDV vaccines was considered for this purpose. Howeyer, the CDV vaccines currently used in dogs are all live attenuated vaccines, which are not recommended for wild live animals, because of the danger of insufficient attenuation, and spread to other wild-animal species ${ }^{14}$. The use of inactivated morbillivirus vaccines has had little success in inducing protective immunity ${ }^{14-17}$. However, we have recently shown that a subunit ISCOM CDV vaccine did induce protective immunity in dogs against challenge with a virulent CDV strain ${ }^{12}$. Another inactivated vaccine, based on adjuvated whole CDV, was recently claimed to be effective in dogs by Duphar BV (personal communication, Dr M. Westrate, Duphar BV, Weesp, The Netherlands), which is being developed for commercial purposes. After having noticed that CDVseronegative seals admitted to the seal sanctuary in Pieterburen showed better survival rates during the 
outbreak after vaccination with either of the two vaccines, a CDV vaccination and challenge experiment was performed in CDV-seronegative seals. This experiment with these CDV-vaccines, in a small number of adult CDV-seronegative harbour seals, which belonged to a breeding group in The Netherlands is described. These animals had remained free of PDV infection and the clinical symptoms observed during the recent outbreak. A selection of preliminary data obtained in these experiments has recently been published ${ }^{18}$, in order to inform sanctuaries and the nature management organizations about the possibilities of vaccination. Both vaccines tested proved to induce CDV neutralizing antibodies and protection against fatal PDV challenge.

\section{Materials and methods}

\section{Seals}

Experimental vaccination with $\mathrm{CDV}$ vaccine preparations was carried out in two different groups of harbour seals. The first was the group of harbour seals admitted, during the outbreak, to the seal sanctuary of the Seal Rehabilitation and Research Centre at Pieterburen (The Netherlands), where mainly baby seals are routinely nursed until they can be reintroduced to the wild. The second was a breeding group of about 40 harbour seals which had been kept in isolation for many years at the island of Texel in the Dutch Wadden sea. In this group no PDV infection had occurred so far, as was shown by the absence of CDV-specific antibodies in the sera of these seals and by the absence of clinical symptoms. Eight adult seals of this group were used for challenge with PDV after the vaccination- or sham-vaccination series had been completed.

\section{CDV vaccines}

Two different candidate $C D V$ vaccines were used. The first was the candidate subunit CDV-ISCOM vaccine prepared from the Rockborn strain of CDV in collaboration with Coopers Animal Health Ltd (Berkhamsted, UK), as previously described, which predominantly contained the $F$ protein of the virus ${ }^{12}$. The second was an inactivated and adjuvanted whole CDV preparation based on the Onderstepoort strain of CDV, kindly provided by Duphar BV (Weesp, The Netherlands), which is being developed for commercial use.

\section{$P D V$ challenge preparation}

Challenge material consisted of a $0.5 \%$ (v/v) suspension of a pool of spleen, lung and intestinal lymph-node cells taken from three harbour seals, which had died from the disease during the outbreak in the Dutch Wadden sea area. This preparation had been shown to induce distemper-like clinical symptoms, CDV-neutralizing antibody titres and viraemia in SPF dogs, after intraperitoneal and oculonasal inoculation with a $10 \%$ suspension of the same inoculum ${ }^{5}$.

\section{Protection studies}

From 15 August 1988 an experimental CDV vaccination regimen was introduced for the seals admitted to the seal sanctuary in Pieterburen. All seals lacking CDVneutralizing antibodies at admission were vaccinated three times at intervals of $7-14$ days, either with the ISCOM preparation or with the inactivated whole-virus candidate vaccine. Survival rates during the outbreak in this sanctuary were recorded.

In the challenge experiment eight $\mathrm{CDV}$-seronegative adult harbour seals were used, of which two were vaccinated with the CDV-ISCOM vaccine, four with the inactivated adjuvanted whole-virus CDV-vaccine and two with an antigen-free preparation. The animals were vaccinated three times intramuscularly. The first two vaccinations were carried out on days -59 and -42 , followed by a final vaccination on day -10 . Blood samples were collected before starting the experiment, 14 days after the first two vaccinations and on the day of challenge (day 0 ). Ten days after the last vaccination, all eight animals were transferred to a closed swimming pool, where they were challenged via the oculonasal and peritoneal routes with $2 \mathrm{ml}$ of the PDV challenge material. After challenge, clinical signs were recorded and necropsy was performed on animals that died. Body temperatures and weights were determined on days 0,4 , $5,6,7,11,14$ and 21 after challenge, when blood samples were also collected for serological studies.

\section{Serological tests}

Serum samples collected from seals in the sanctuary and from the eight animals in the challenge experiment were examined for their levels of CDV-specific antibodies by a CDV antibody ELISA (CDV-ELISA), a CDV neutralization assay (CDV-VN) and in a Western blot assay.

CDV ELISA. ELISA was carried out essentially as described for the detection of measles virus specific antibodies $^{12}$. In short, CDV (Bussel strain ${ }^{19}$ ) -infected Vero cells, showing complete cytopathologic effect (cpe), were lysed by freeze-thawing and after low-speed centrifugation the resulting suspension was used for overnight coating (RT) in carbonate buffer (pH 9.6). A non-infected Vero cell preparation treated in the same way served as a control antigen. HRPO-labelled rabbit-anti-seal serum, raised against protein-A purified seal immunoglobulins was used as second antibody. ELISA titres were determined by measuring the serum dilutions still giving $50 \%$ of the maximum substrate reaction and expressed as the reciprocal of these dilutions.

$C D V-V N$. Neutralization assays were carried out as described previously, using the Bussel strain of CDV, Vero cells and serial threefold serum dilutions ${ }^{12}$. VN titres were expressed as the reciprocal of the serum dilutions still giving complete reduction of cpe, using 100 TCID $_{50}$.

Western blot assay. The protein specificities of serum antibodies raised upon immunization with the different vaccines and upon challenge were examined by Western blot analysis essentially as described by Towbin et $a .^{20-23}$. The proteins of sucrose gradient $(30-60 \%$ sucrose in TN buffer)-purified CDV (Rockborn strain) were separated on a $12.5 \%$ SDS-polyacrylamide gel $^{24}$, after which they were electrophoretically transferred to nitrocellulose sheets $(0.2 \mu \mathrm{m}$ Schleicher and Schuell). To prepare the sheets for imminostaining, additional protein-binding capacity was blocked by a $1 \mathrm{~h}$ incubation at $37^{\circ} \mathrm{C}$ with blot buffer (PBS supplemented with $0.05 \%$ (v/v) Tween 80, 1\% (w/v) BSA, 5\% (v/v) SPF rabbit 


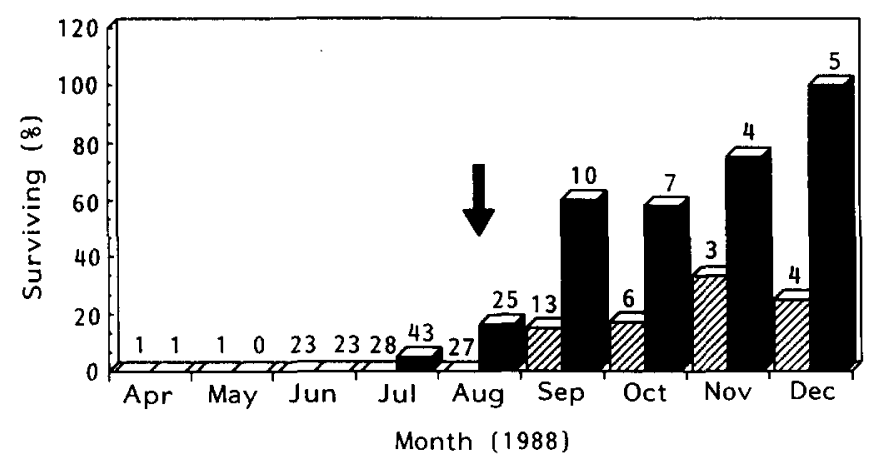

Figure 1 Percentages of seals surviving in the Seal Sanctuary Pieterburen from April to December 1988. Number of seals admitted monthly are shown above each column: $\square$, with CDV-neutralizing serum antibodies (titre $\geqslant 20$ ); 2 , without CDV-neutralizing serum antibodies. From 15 August (arrow) seals that were admitted without CDVneutralizing serum antibodies were vaccinated with either of the two candidate CDV-vaccines

serum and $5 \% \mathrm{NaCl}$ ). Serum samples taken at different times during the experiment were diluted 1:50 in blot buffer and incubated for $1.5 \mathrm{~h}$ on nitrocellulose strips. The strips were washed twice with tap water and subsequently twice for 5 min with PBS containing $0.05 \%$ Tween 80 (PBS-T). Strips were then incubated for $1 \mathrm{~h}$ at $20^{\circ} \mathrm{C}$ with an $\mathrm{HRPO}$-labelled rabbit-anti-seal preparation diluted in blot buffer, washed again with tap water and PBS-T and stained using TMB/DONS as described ${ }^{25}$.

\section{Antigen demonstration}

Morbillivirus antigen present in organ material taken from the two sham-vaccinated seals after capture was detected by an antigen-detection ELISA and/or an immunofluorescence assay (IFA).

Antigen-capture ELISA. An antigen-capture ELISA was used to detect PDV antigen in $10 \%$ (v/v) suspensions of lung, brain, spleen, kidney and liver samples, essentially as previously described ${ }^{26}$. The F-specific monoclonal antibody A 1074 (clone 5006), kindly provided by Dr C. Orrvell ${ }^{27}$, was used as a coating to the microtitre plate (Costar EIA/RIA Strip plate-8) (overnight, $20^{\circ} \mathrm{C}$ ), on which the different organ suspensions were incubated overnight at $4^{\circ} \mathrm{C}$. After incubation for $1 \mathrm{~h}$ at $37^{\circ} \mathrm{C}$ with polyclonal hyperimmune anti-CDV dog serum followed by incubation for $1 \mathrm{~h}$ at $37^{\circ} \mathrm{C}$ with HRPO-labelled goat-anti-dog-IgG/IgM (Cappel), staining was provided using TMB as a substrate as described ${ }^{12}$.

Immunofluorescence assay. Immunofluorescence analysis of CDV-like antigen was carried out on cryostat sections of different organs, using the anti-F monoclonal antibody A 1074 (C. Örvell) and an anti-mouse FITC conjugate (Dakopatts), as described previously ${ }^{28}$.

\section{Post-mortem investigation}

Gross necropsy was performed on the two shamvaccinated seals that had died. Several tissues were sampled for additional histopathological examination. After fixation in Bouin's fixative or in a phosphatebuffered neutral $4 \%$ formaldehyde solution, $4 \mu \mathrm{m}$ paraplast-embedded tissue sections were stained with haematoxylin and eosin and examined under the light microscope.

\section{Results}

Antibody development and survival of seals in the Seal Sanctuary, Pieterburen

From 15 August 1988 all seals admitted to the seal sanctuary in Pieterburen that had no CDV-VN serum antibody titre upon admission (titre $<10$ ) were vaccinated three times, either with the candidate CDV ISCOM or with the candidate inactivated whole $\mathrm{CDV}$ vaccine. CDV-VN antibody titres in surviving seals, measured $>2$ months after admission, ranged from 30 to 3000 $(\bar{x}=810)$ in the vaccinated animals and from 100 to 300 $(\bar{x}=270)$ in those non-vaccinated animals with CDV-VN serum antibodies on admission. No clear differences in survival rates or antibody development were observed between the groups of animals vaccinated with either of the two vaccines. Vaccination of the seals with these vaccines appeared to induce protection, as it resulted in a dramatic decrease in the mortality rates compared with the non-vaccinated group: survival percentages increased from $<10 \%$ to $>60 \%$ within 1 month, whereas they remained $<30 \%$ in the non-vaccinated animals (Figure 1).

\section{Antibody development and survival of seals in the experimental group}

The development of CDV-VN serum antibodies upon vaccination was recorded in the experimental group. The two seals vaccinated with the ISCOM preparation and
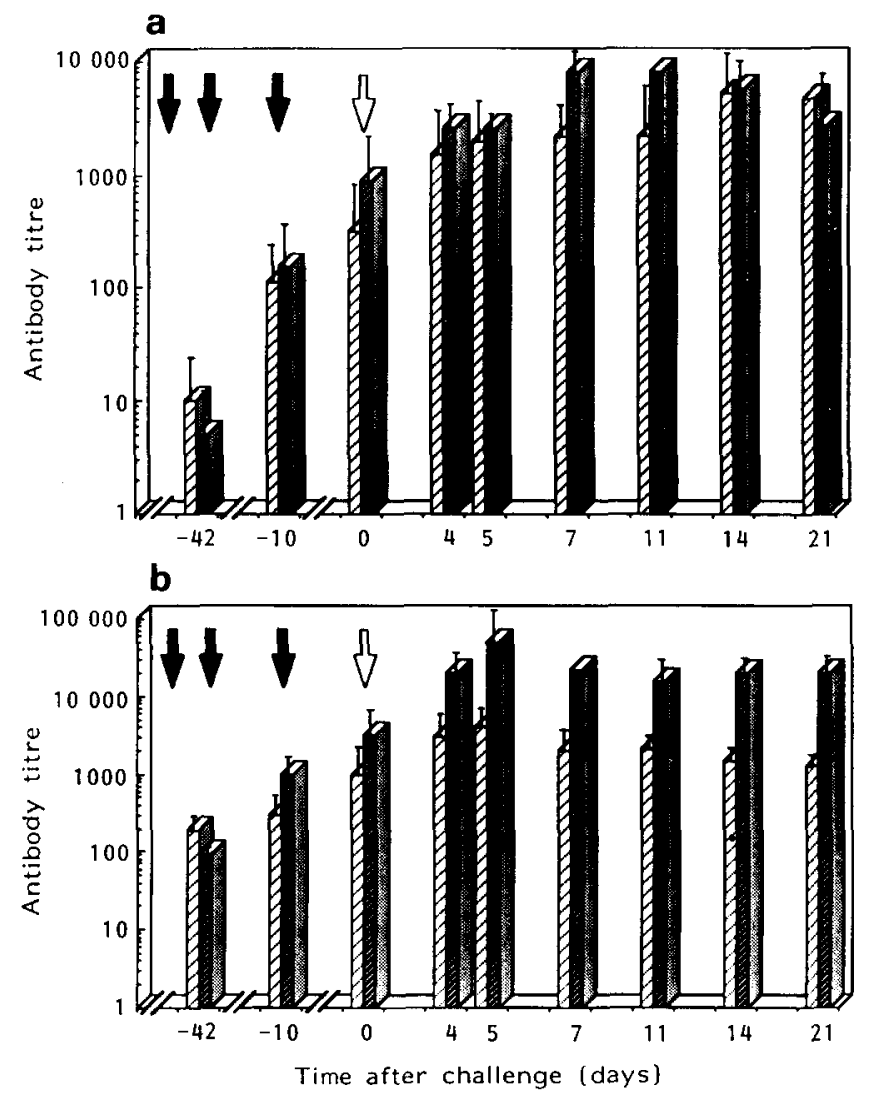

Figure 2 (a) Development of CDV-VN serum antibody titres and (b) CDV-ELISA serum antibody titres in the experimental group of seals after three vaccinations on day $-59,-42$ and -10 (dark arrows), as measured on day -42 , day -10 and day 0 (day of challenge) and upon challenge (open arrow) as measured on days 4, 5, 7, 11, 14 and 21 after challenge: $⿴ 囗 ⿰ 丿$, ISCOM-CDV vaccinated seals; $\square$, inactivated whole CDV vaccinated seals 


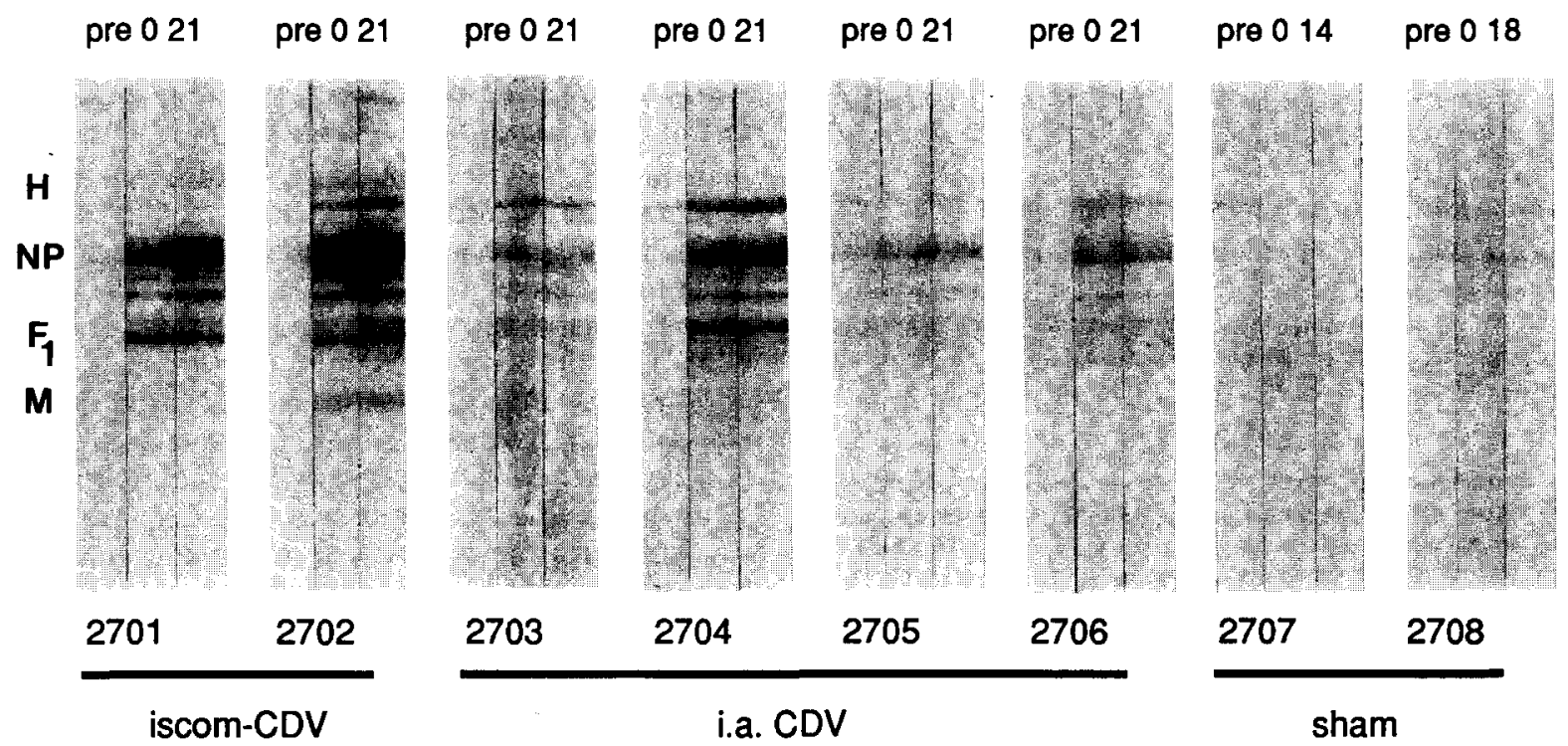

Figure 3 Western blot analysis of serum samples taken before vaccination (pre), after vaccination (day 0) and after challenge (No. 2701-No. 2706: day 21; No. 2707 and No. 2708 ; day 14 and 18 respectively) from eight seals involved in the challenge experiment that were vaccinated with the ISCOM-CDV vaccine (No. 2701 and No. 2702), with the inactivated whole CDV vaccine (i.a. CDV) (No. 2703, No. 2704, No. 2705 and No. 2706), or with the antigen-free preparation (sham) (No. 2707 and No. 2708)

Table 1 Clinical signs upon challenge observed in two sham-vaccinated seals

\begin{tabular}{|c|c|c|c|c|c|c|c|c|c|c|c|c|c|c|c|c|c|}
\hline \multirow[b]{2}{*}{ Seal no. } & \multirow{2}{*}{$\begin{array}{l}\text { Weight loss } \\
\text { (kg on day 14) }\end{array}$} & \multicolumn{5}{|c|}{$\begin{array}{c}\text { Body temperature } \\
>1^{\circ} \mathrm{C} \text { above } \\
\text { normal on day: }\end{array}$} & \multicolumn{5}{|c|}{$\begin{array}{l}\text { Nasal discharge } \\
\text { and/or respiratory } \\
\text { distress on day: }\end{array}$} & \multicolumn{6}{|c|}{$\begin{array}{l}\text { Neurological } \\
\text { symptoms on } \\
\text { day: }\end{array}$} \\
\hline & & 0 & 7 & 11 & 14 & 18 & 0 & 7 & 11 & 14 & 18 & 0 & 7 & 11 & 14 & 17 & 18 \\
\hline 2707 & 5.1 & - & - & - & $\dagger$ & & - & - & + & $\dagger$ & & - & - & - & + & & \\
\hline 2708 & 11.4 & - & - & + & + & $\dagger$ & - & - & - & + & $\dagger$ & - & - & - & - & + & $\dagger$ \\
\hline
\end{tabular}

+ , Presence of elevated body temperature, signs of respiratory distress or neurological signs as indicated; $\uparrow$, dead

the four vaccinated with the inactivated vaccine all developed titres gradually increasing from 10 to 1000 during the vaccination procedure. During the period following challenge, the titres further increased in both groups to levels between 1000 and 10000 (Figure $2 a$ ). A similar pattern of antibody development was observed when the sera were tested in the CDV-ELISA (Figure $2 b$ ). Of the sham-vaccinated seals, one developed CDVspecific serum antibodies upon challenge as detected in CDV-VN (titre 30) and in CDV-ELISA (titre 100), whereas the other remained seronegative to CDV in both assays. However, the development, upon challenge, of PDV-specific antibodies, not cross-reacting with CDV, cannot be ruled out on the basis of these data.

Development of serum antibodies, after vaccination and challenge, to the respective structural CDV proteins was monitored in all these animals by Western blot analysis. Although the CDV-ISCOM preparation predominantly contained the $F$ protein, antibodies to other viral proteins were also induced upon vaccination, as had also been noticed in experiments in dogs ${ }^{12}$. In one of the two ISCOM-vaccinated seals (No. 2701), a pronounced antibody development to the NP and F proteins was observed after vaccination, which did not change significantly upon challenge. The other ISCOMvaccinated seal (No. 2702) developed antibodies to these and also to the $\mathrm{H}$ and $\mathrm{M}$ proteins, which response also did not change significantly upon challenge (Figure 3).
The seals vaccinated with the inactivated vaccine predominantly developed antibodies to the NP and F proteins, which responses also did not alter upon challenge. No antibody development could be detected by Western blot analysis against CDV proteins in the sham-vaccinated animals upon vaccination and challenge.

Upon challenge, the six vaccinated seals survived for at least the whole experimental period ( 5 months) whereas the sham-vaccinated seals died on days 14 and 18 respectively.

\section{Clinical signs and post-mortem findings in the experimental group}

All six vaccinated seals remained free of clinical signs indicative of phocid distemper. The two sham-vaccinated seals, however, developed symptoms of distemper including respiratory distress, mucopurulent nasal discharge, elevated body temperature and weight loss after challenge. These symptoms were similar to those observed in and outside the seal sanctuary during the distemper outbreak $^{2,4,5,9,29}$. One of them (No. 2708) also developed convulsive seizures, which, together with other neurological symptoms, are regularly observed in animals with phocid distemper ${ }^{1,29}$ (Table 1). They died on days 14 and 18 , respectively.

Investigation of organ suspensions of both dead seals (No. 2707 and No. 2708) for the presence of morbillivirus 


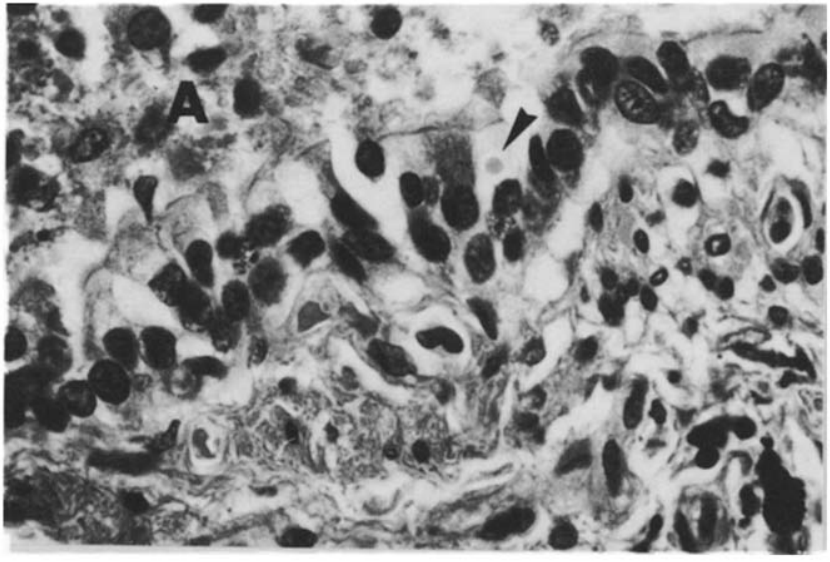

Figure 4 Eosinophilic cytoplasmic inclusion body in a bronchial epithelial cell (arrow). Desquamative and purulent exudate is present in the lumen (A). (HE $800 \times$ )

antigen in the antigen-ELISA, yielded a positive result with the spleen suspension of seal No. 2707 and with the lung suspension of seal No. 2708. In the latter, morbillivirus antigen was also demonstrated by indirect IFA on cryostat sections of the lungs.

Gross necropsy of the sham-vaccinated animals revealed signs compatible with the clinical findings, i.e. mucopurulent nasopharyngitis, notably in No. 2708, and severe emaciation with atrophy of the subcutaneous adipose layer and a decreased volume of the intestinal tract. Haemochromatosis, mainly hepatic, was seen in both animals. Seal No. 2707 was suffering from a membranous glomerulopathy. The most striking histopathological finding consisted of cytoplasmic inclusion bodies, which were found in bronchial epithelium and in the renal pelvic urothelium of one animal (Figure 4). They were rounded and sharply delineated, eosinophilic and sometimes multiple.

\section{Discussion}

Recent evidence, mainly consisting of virus isolation and serological data, has shown that the primary cause of the recent epizootic among seals in north-western Europe was infection with a morbillivirus (PDV) closely related to, but probably distinct from, $\mathrm{CDV}^{2,4-9,11,18}$. For final proof of the aetiological role of PDV, a challenge experiment in seals, which either had, or had not previously been exposed to or vaccinated against PDV was necessary ${ }^{5,18}$. In the present paper we have shown, that harbour seals could, indeed, be protected against phocid distemper with certain inactivated CDV vaccines, confirming the close antigenic relationship between these two morbilliviruses. This had already been indicated by results of cross-VN, ELISA, IFA and nucleic acid hybridization studies ${ }^{5-8,16}$. Indications that these vaccines induced protection had already been obtained at the Seal Sanctuary, Pieterburen, by demonstration of a clear difference between survival of vaccinated versus nonvaccinated seals. Although it can be argued that the non-vaccinated animals were already infected with PDV before admission, it could be concluded from the data, presented in Figure 1, that PDV did spread rapidly through the sanctuary, implying that the vaccinated seals must also have been exposed to PDV-infection during their stay in the sanctuary. The symptoms observed in the two sham-vaccinated seals, which died in the experimental group after challenge with material that had been shown to contain infectious PDV in a previous experiment in SPF dogs ${ }^{5}$, included weight loss, fever, respiratory disease and neurological symptoms. These were symptoms which have also been observed in animals suffering from the disease in and outside the sanctuary ${ }^{2,4,9,11,26}$. In the six vaccinated animals, such symptoms were not recorded. Viral antigen was detected in tissues of the sham-vaccinated seals after death and, in one of them, cytoplasmic inclusion bodies were found in lung and kidney. The presence of morbillivirus RNA was demonstrated in the spleens of both animals (T. Barrett, Institute for Animal Health, Pirbright, UK, unpublished observations). The serum antibody responses to PDV, as measured on the basis of their cross-reactivity to CDV in CDV-VN, CDV-ELISA and Western blot, in these vaccinated seals indicated that all these animals had developed high levels of serum antibodies to CDV and PDV, and probably protective immunity against the latter, which was a prerequisite for performing the challenge infection. Although after the challenge a slight increase in serum antibody titres in the CDV-VN and CDV-ELISA was observed (which was not, however, demonstrable in the Western blot analysis), it cannot be concluded from these data that PDV replicated in the vaccinated animals after challenge, because this increase could also be attributed to the vaccination procedure itself. The absence of CDV-VN and CDV-ELISA antibodies in one of the sham-vaccinated seals and the absence of antibodies reactive with $\mathrm{CDV}$ proteins in Western blot analysis in both upon challenge with PDV, may perhaps be attributable in part to antigenic differences between CDV and PDV. The animals could, in the short period after challenge, have developed low-titred PDV-specific antibodies, not detectable in the heterologous assays. In principle, the successful results obtained in this vaccination experiment indicates, (although only a limited number of seals were included) that seals can, indeed, be protected by vaccination with inactivated $C D V$ vaccines against phocid distemper. For several reasons, vaccination will be limited to seals kept in captivity in sanctuaries and zoos. Apart from the fundamental question of whether vaccination of wild animals should be considered at all, it is not only difficult and stressful to capture animals in the wild, but also a multiple-dose regimen would not be practical ${ }^{13}$. Further studies to evaluate the duration of immunity, the possibility of reduction of the number of subsequent vaccinations and, perhaps, the eventual change from vaccination with $C D V$ vaccines to a genuine inactivated PDV vaccine, should be conducted.

\section{Acknowledgements}

The authors are grateful to $\mathrm{Mr} \mathrm{C}$. Zegers and Mr S. de Wolf for their outstanding animal handling, to $\mathrm{Mr} \mathrm{H}$. Broeders and Ms I. Spijkers for technical assistance, to Ms J. Robinson for preparation of the cryostat sections and to Ms C. Kruyssen for help in preparing the manuscript. We especially acknowledge $\mathrm{Mr} \mathrm{J}$. de Jong for his valuable contribution and the Seal Sanctuary in Pieterburen for financial support. 


\section{References}

1 Osterhaus, A.D.M.E. Seal death. Nature 1988, 334, 301

2 International workshop seal disease epidemic, Research Institute for Nature Management, 17-18 January, 1989, Texel, The Netherlands

3 Reijnders, P.J.H. The recent virus outbreak amongst harbour seals in the Wadden Sea: Possible Consequences for Future Population Trends. Wadden Sea Newsletter 1989, 1, 10

4 Osterhaus, A.D.M.E. and Vedder, E.J. Identification of virus causing recent seal deaths. Nature 1988, 335, 20

5 Osterhaus, A.D.M.E., Groen, J., De Vries, P., UytdeHaag, F.G.C.M. Klingeborn, B. and Zarnke, R. Canine distemper virus in seals. Nature 1988, 335, 403

6 Kennedy, S., Smyth, J.A., McCullough, S.J., Allan, G.M., McNeilly, F. and McQuaid, S. Confirmation of the cause of recent seal deaths. Nature 1988, 335, 404

7 Mahy, B.W.J., Barrett, T., Evans, S., Anderson, E.C. and Bostock, C.J. Characterization of a seal morbillivirus. Nature 1988, 336, 115

8 Cosby, S.L., McQuaid, S., Duffy, N., Lyons, C., Rima, B.K., Allan, G.M. et al. Characterization of a seal morbillivirus. Nature 1988, 336, 115

9 Hofmeister, R., Breuer, E., Ernst, R., Hentschke, J., Mölle, G. and Ludwig, $H$. Distemper-like disease in harbor seals: virus isolation further pathologic and serologic findings. J. Vet. Med. B 1988, 35, 765

10 Appel, M.J.G. Canine distemper virus. In: Virus Infections of Vertebrates, Volume 1 (Ed. Horzinek, M.C.) Elsevier, Amsterdam, 1987 , p. 133

11 International Workshop on Current Research in Seal Diseases Hanover Veterinary School, 21-22 February 1989, Hanover, Germany

12 De Vries, P., UytdeHaag, F.G.C.M. and Osterhaus, A.D.M.E. Canine distemper virus (CDV) immune-stimulating complexes (iscoms), but not measles virus iscoms, protect dogs against CDV infection. $J$. Gen. Virol. 1988, 69, 2071

13 Emergency Scientific Working Group on the evaluation of possibilities for vaccination against the causative agent of the recent seal deaths in the Baltic and North Seas, 16 September, 1988 Amsterdam, The Netherlands

14 Appel, M.J.G. Reversion to virulence of attenuated canine distemper virus in vivo and in vitro. J. Gen. Virol. 1978, 41, 385

15 Gillespie, J.H. A study of inactivated distemper virus in the dog Cornell Vet. 1974, 55, 3

16 Norrby, E., Enders-Ruckle, G. and Ter Meulen, V. Differences in the appearance of antibodies to structural components of measles virus after immunization with inactivated and live virus. J. Infect.
Dis. 1975, 132, 262

17 Appel, M.J.G., Shek, W.R., Shesberadaran, H. and Norrby, E. Measles virus and inactivated canine distemper virus induce incomplete immunity to canine distemper. Arch. Virol. 1984, 82, 73

18 Osterhaus, A.D.M.E., UytdeHaag, F.G.C.M., Visser, I.K.G., Vedder, E.J., Reijnders, P.J.H., Kuiper, J. and Brugge, H.N. Seal vaccination success. Nature 1989, 337, 21

19 Bussell, R.H. and Karzon, D.T. Canine distemper virus in primary and continuous cell lines of human and monkey origin. Arch. Ges. Virus Forsch. 1965, 17, 183

20 Towbin, H., Staehelin, T. and Gordon, J. Electrophoretic transfer of proteins from polyacrylamide gels to nitrocellulose sheets; procedure and some applications. Proc. Natt. Acad. Sci. USA 1979, 76, 4350

21 Rima, B.K. The proteins of morbilliviruses. J. Gen. Virol. 1983, 112, 195

22 Hirayama, N., Senda, M., Yamamoto, H., Kurata, K., Yoshikawa, Y. and Yamanouchi, K. Comparison of biological and molecular properties among canine distemper virus strains. Jpn. J. Vet. Sci. $1986,48(2), 259$

23 Campbell, J.J., Cosby, S.L., Scott, J.K., Rima, B.K., Martin, S.J. and Appel, M. A comparison of measles and canine distemper virus polypeptides. J. Gen. Virol. 1980, 48, 149

24 Laemmli, U.K. Cleavage of structural proteins during the assembly of the head of bateriophage T4. Nature 1970, 227, 680

25 De Vries, P., Van Binnendijk, R.S., Van der Marel, P., Beuvery, E.C., Van Wezel, A.L., Voorma, H.O. et al. Inhibition of measles virus induced cell-cell fusion with a monocional antibody directed against the haemagglutinin. Viral Immunol. 1987, 1, 25

26 Rimmelzwaan, G.F., Groen, J., Juntti, N., Teppema, J.S., UytdeHaag, F.G.C.M. and Osterhaus, A.D.M.E. Purification of infectious canine parvovirus from cell culture by affinity chromatography with monoclonal antibodies. J. Virol. Meth. 1987, 15, 313

27 Shesberadaran, H., Norrby, E., McCullough, K.C., Carpenter, W.C and Orvell, $C$. The antigenic relationship between measles, canine distemper and rinderpest viruses studies with monoclonal antibodies. J. Gen. Virol 1986, 67, 1381

28 Groen, J., Van Der Groen, G., Hoofd, G. and Osterhaus, A.D.M.E. Comparison of immunofluorescence and enzyme linked immunosorbent assays for the serology of hantaan virus infections. J. Virol Meth. 1989, 23, 195

29 Osterhaus, A.D.M.E., Groen, J., Spijkers, H.E.M., Broeders, H.W.J., UytdeHaag, F.G.C.M., De Vries, P. et al. Mass mortality in seals caused by a CDV-like morbillivirus. J. Vet. Microbiol., submitted for publication 